\title{
Regulatory For Structuring Of Small Business In Developing Tourism Destination
}

\author{
Ni Luh Made Mahendrawati ${ }^{1}$, A.A. Gede Oka Wisnumurti ${ }^{2}$, I Nyoman Sujana ${ }^{3}$ \\ \{made.mahendrawati@gmail.com\} \\ Program Magister Kenotariatan Universitas Warmadewa
}

\begin{abstract}
The development of an area to become a tourism destination inevitably involves many cooperating parties and a systematic and integrated regulation with other sectors. In order to create an orderliness there is a need for a business legal approach to be involved so that tourism activities do not bring about unendurable negative impacts. One of the negative impacts in question is the occurrence of unfair business competition, especially between small business actors in tourism destinations. Thus, there is a need of regulatory model for structuring small businesses in the tourist destination. Hence, in the present study we made use of normative study design to explore the regulatory model for structuring small businesses from a juridical, sociological and philosophical perspective. We dealt with discovering an alternative model that is best used in regulating the appropriate structuring of small business so that fair business competition does occur. Access to economic resources in the tourism sector can be obtained fairly by all entrepreneurs both of micro and macro levels.
\end{abstract}

Keywords: Regulatory Model, Small Business, Tourism Destinations

\section{Introduction}

Tourism is a person's travel activities from one place to another within a certain period of time [1]. Referring to Law No. 10 of 2009 concerning Tourism (Law No. 10 of 2009) the notion of tourism is determined to be "various kinds of tourism activities and supported by various facilities and services provided by the community, businessmen, government, and local government". In the same law, tourism is defined as "travel activities carried out by a person or group of people to visit certain places for recreational purposes, self-development, or to study the uniqueness of tourist attractions visited in the interim period". With regard to these concepts, there are several elements in the concept of tourism, including:

1. Tour

2. Facilities and services

3. Community

4. Businessmen

5. Government and local government

Such nature of tourism represents how complex the activities in the tourism sector are as a result of the involvement of many stakeholders in its implementation. 
In this study, a point of view that focuses the efforts by returning authority to the government that holds the role of policy (legal regulation) to be able to accommodate the interests of employers and the community in the implementation of tourism activities (implementation of the tourism sector) is revived. To realize this, a developmental model that is integrated with other arrangements, especially in the business field, is needed. Tourism area development has an impact on the emergence of small businesses around the tourist destination area. If these small businesses are not structured and organized well, they will certainly lead to a less neat view and even trigger deterioration of environmental pollution. In the business aspect, the resulted negative impact is that unhealthy competition between small business actors will dominate the atmosphere.

Further, there are some preceding research related to small business in developing tourism destination. Firstly, a research conducted by [2] that focuses on the complexity and multidimensional nature of small tourism business performance, aspects pertaining to competitive advantages, and the enterprise development issues arising from the prioritization of lifestyle objectives over those of a more explicit economic nature. Finally, lifestyle prioritized over business may be interpreted as sub-optimal in rational economic terms. Conversely the consequential, deliberate protection and conservation of 'smallness' may represent an important contributor to the achievement of competitive advantage. Secondly, a research carried out by [3] the results showed that the existence of regulation does not determine its effects. Regulation produces performance effects even where these display no regular pattern, or where effects are unperceived by small firms, stakeholders or third-party observers. The influence of regulation critically depends on how small business agents, and the stakeholders with whom they interact - including actual and prospective customers, suppliers, competitors, infrastructure providers and regulatory authorities-adapt to regulation.

Thirdly, a research done by [4]. This research refers to alternative futures in tourism, finally, it can be concluded that the system that needs to be built with this transformation of mass tourism is one that creates the elements of 'host' and 'visitor' on a friendship or kinship basis, and a cost-effective transit system. It has far-reaching implications for population movements, decentralization of industries, development of non-commodity market activities, and land-use policies. It is not very much like the system that was developing around mass tourism. Based on the explanation above, the present study aims to explore the regulatory for structuring of small business in developing tourism destination.

\section{Method}

This study was conducted using normative research method. In accordance with the outcomes to be achieved in this study, several relevant approaches to the results expected to have been used. The approaches are statue approach and conceptual approach. Additionally, according to the type of research carried out, the source of data and legal materials are obtained from several related literature, legislation and literature sources that have the validity value of the study. We collected previous studies examining the related objects to that of the present one to review how far the social sciences have revealed out strategic efforts of various parties to help minimize unfair competition among business actors within tourism sector. We collected Indonesian legal regulations governing tourism sector, tourism activities, and business actors. By making discussion between the results of previous related studies, we could highlight which model has not been offered to structure small business in its relation to 
develop tourism destinations to then be offered as an alternative regulatory model for the structuring of small business. Legal materials collected were processed by providing legal reasoning patterns to be argued in descriptive form.

\section{Results And Discussion}

\subsection{The Orientation of Tourism Destination Development in the Dimension of National Development}

The dynamics of tourism development are unavoidable. The tourism sector is driven by small sectors as a supporting element. The parties as a driving element of tourism like the community, the Government, and the Regional Government are the main triggers that take control in the dynamics of tourism development. Because of this, for the purpose of making the tourism in line with the spirit of national development can be carried out, the role of the parties that are interrelated with one another in an integrated and sustainable manner is demanded. The government plays a dominant role in the field of tourism policy. The forms of structuring the tourism policies include the following:

1. Implementation of concepts, principles, requirements, technical standards of economics, trade, trade in services, and in particular trade in tourism services in tourism activities in Indonesia;

2. Identification of relations, forms, requirements, treatment and obligations - the obligation of tourism business actors, in the form of cultural and social responsibility, towards the culture and the supporting community;

3. Governing legal policies [5].

Policy of law on the field of tourism must be integrated with that of other fields, so that it is of a crucial nature to direct tourism policy in reference to national legal policies. As a basis for everything, there is the urge to master the national policy as a parameter in determining policy orientation in the tourism sector.

The national development policy orientation is set out in Law Number 25 of 2004 concerning the National Development Planning System (Law No. 25 of 2004). In Article 1 number 2, it is explained that national development is an effort carried out by all components of the nation in order to achieve the purpose of the state. The purpose of the state as stated in paragraph 4 of the Preamble of the Constitution of the Republic of Indonesia is to realise a social welfare through protection, improvement of human resources, and efforts to carry out foreign policy, all of which are based on the noble values of Pancasila, the five principles of the Republic of Indonesia. The purpose of the Indonesian State in political configuration is realized in several stages as exposed in the explanation of Law No. 25 of 2004 encompassing: (1) preparation of plans; (2) plan determination; (3) control of the implementation of the plan; and (4) evaluation of the implementation of the plan. The four stages are held on an ongoing basis so as to form each of planning cycle as a whole. Furthermore, in the same article of the same Law the determination of the plan is realised to be a legal product so that it binds all parties to implement it.

Based on national development goals, tourism development is also directed at national development goals. As a derivative of Law No. 10 of 2009, the orientation of tourism policy is outlined in the Republic of Indonesia Government Regulation Number 50 of 2011 concerning the National Tourism Development Master Plan for 2010-2025 (Government Regulation No. 50 of 2011). In Article 2 paragraph (1) Government Regulation No. 50 of 2011 stated that in 
realizing the vision of national tourism development as referred to in paragraph (4), there are four national tourism development missions that must be pursued, encompassing the development of tourism destinations, tourism marketing, tourism industry and tourism institutions. Tourism institutions include government organizations, local governments, the private sector and the community, human resources, regulations, and effective and efficient operational mechanisms. In the sociological dimension, it can be seen that a group of humans who live together and interact with one another or interact with their environment become social beings, so that the collection of people is called the community [6]. In the context of tourism destinations, there are no clear arrangement about which people are referred to as communities. If interpreted what is meant by community here is a society around a tourism destination that is directly interact within the tourism activities at the area of the tourist destination. All forms of policy in the tourism sector should not deny the general purpose as well as the objectives of the community, because in fact the dimensions of the axiology of the community give rise to strong and fundamental relations with the aim of the implementing the national tourism, as well as national goals.

\subsection{Regulatory of Small Businesses in Developing Tourism Destinations as a Form of Economic Democracy}

Regarding small businesses in Indonesia it is regulated in Law No. 20 of 2008 concerning Micro, Small and Medium Enterprises. In Article 1 Number 2 it is determined that Small Enterprises shall be productive economic businesses standing alone, done by individual persons or business entities not constituting subsidiaries or not constituting company branches owned, controlled, or becoming direct or indirect portions of Medium or Large Enterprises that meet the criteria of Small Enterprises as intended herein. Small businesses that are one of the government's concerns to be empowered with the following considerations:

1. Small businesses include one of the pillars of economic development that is fostered and protected by the government.

2. Small businesses have the potential to develop so that they can plunge into the global economic arena.

3. With the existence of business resilience and independence, the people's economy has prospects in future free market competition.

The development of small businesses is a series of efforts carried out by the government in the form of policies in an effort to create national economic stability. Therefore, structuring small businesses in the development of tourism destinations is one of the keys to achieving national tourism goals and national goals. Regarding tourism, the government established the Republic of Indonesia Government Regulation Number 50 of 2011 concerning the 2010 2025 National Tourism Development Master Plan (hereinafter referred to as PP 50/2011). It is a form of synergy in the form of harmonizing regulations as a positive rule of law in engineering society and its tourism environment. Synergy in empirical form is in the form of its application in the field, so that it requires supervision, enforcement and resolution of all problems that arise.

The orientation of the implementation and development of Indonesian tourism is determined in Article 3 of the Tourism Law, that is, "Tourism affairs shall have function to fulfill the physical, spiritual and intellectual needs 7 of every tourist with recreation and travel as well as increase the state revenues to materialize the people's welfare". The final goal of tourism is fair and equitable welfare felt by the people. The essence of justice and evenness is intended to avoid the climate of tourism which is characterized by liberal ideologies that are synonymous with capitalism. It is realized that tourism business, which is a very broad terminology, 
involves so many stakeholders. Freedom seeks to cause the emergence of many entrepreneurs who want to obtain economic implications directly from the tourism sector. A climate of unfavorable business competition will actually lead to conflict of interest, which leads to chaos. Therefore, there is an urgent situation to redirect policy orientation in the development of tourism businesses towards a prosperous society through a climate of healthy competition based on economic democracy.

Etymologically, democracy is derived from the term "demos" means people and "cratein" means to rule, and thus democracy is a governance held by the people [7]. In the context of the term "economic democracy" there is certainly a shift in the definition of the notion of independent democracy. Before that, it seemed appropriate to examine the nature of economics as a science. Through the approach of philosophy, it can be seen that humans are rational beings, who are always willing to experience improvement/maximization for their welfare. To achieve both of these, they do what they feel is best to do [8]. This is in line with Bentham's utilitarianism, in fact humans have the principle of seeking as much pleasure as possible [9]. The economy is essentially all rational human actions based on its orientation towards happiness. Happiness is an abstract entity that can only be felt by subjective indicators, so that in its development the idea of using numbers (numeric) as an indicator of happiness emerges. Number indicators that are considered more objective then shift the indicator's "taste" subjectivity as a measure of happiness

Moving on from each of the terms above, economic democracy refers to people's power (individuals) to realize their natural instincts to achieve numerical happiness which is then identified with money. In order to better understand democracy, there is a line to understand the constituent elements that are always there to be said to be democracy (ontological aspects). Sargent points out several elements that generally exist in ideology called democracy, as follows:

"...element of democracy or at least of those elements normally considered significant. They are:

1. Citizen involvement in political decision making

2. Some degree of equality among citizens

3. Some degree of liberty or freedom granted to or retained by citizens

4. A system of representation

5. An electoral system-majority rule [10].

In line with this idea, one of the elements in the ideology of democracy is "liberty" or "freedom" that is owned by society (individuals). Regarding Locke's view, the creation of a state is the result of a community agreement. The agreement shall be deliberately made by the community to the authorities to lead the country by taking part in the community's rights to be regulated. Meanwhile, some of the rights are still held by each individual. It is this science fiction that then hacks into the dichotomy in legal science in the form of public law which is born from state-owned rights, and private law which is born from the rights owned by individuals [11].

Freedom is a term widely discussed by Mill in her book "On Liberty". In summary, Mill's thinking leads to individual freedom to realize happiness. That's because people's happiness can consist of happiness in the majority of individuals, but not the happiness of all individuals. Building on this, it is important to measure the happiness of an individual so that it can be achieved by paying attention to the happiness of other individuals so as not to intersect. General happiness is created by bringing together the happiness of each individual [12]. Referring to the nature of democracy mentioned above, economic democracy can be interpreted as an individual's freedom to rationally choose everything related to his economy. 
Therefore, one or several people are given the freedom to do business in order to obtain happiness numerically (economically). Individual freedom to do business is pursued in order to continue to create a climate of good and healthy competition. In this case, the right of the state to regulate in the form of legal policies (forming, supervising and enforcing) in the economic field is carried out to realize fair business competition.

Economic democracy is a principle in the administration of the economy. In essence the implementation of the economy can lead to two types of big ideologies known to the world namely capitalism or socialist. Capitalism has several characteristics, including having private property rights, no ownership limits, and no government interference in the economy (free market system). Meanwhile, socialist ideology has a character that is contrary to capitalist character [10]. The freedom given to individuals to carry on efforts in the economic field will lead to a monopoly on human resources, market areas, raw materials, etc. Such conditions will actually lead to significant differences that are owned by individuals with one another in access to the economy. The highest welfare will be owned by capitalists or those who control the largest resources and means of production. To anticipate this, there is a need for actions and efforts to direct economic democracy in Indonesia based on Pancasila.

Pancasila is the ideology of the Indonesian nation and state. Pancalisa as an ideology is not rigid and not closed but is open. It is intended that the Pancasila ideology is actual, dynamic, anticipatory and always able to adjust to the times [13]. Pancasila values must be maintained but are embodied in broader insight so as to be able to answer actual challenges in a concrete manner. In abstract, Pancasila values can be identified sequentially from percept I to percept V: Divinity values, Moral values (humanity), Unity values, Democratic values and the value of Social Justice. To realize social justice, in the sense of anticipating the formation of capitalism in the economy, there is a need for strengthening democracy based on Pancasila. Pancasila based democracy is intended as a democracy imbued by the values of Godhead, humanity and unity (the fourth precepts are dominated by the first, second and third precepts). In line with Pound's opinion, law functions as a social engineering tool. Therefore, to form economic democracy, there is a need for inevitably government regulation in the form of a legal regulation that contains orders and prohibitions in creating a fair business competition climate, which in this context is a fair business competition climate in tourism business.

\subsection{Regulatory Model of Structuring of Small Business in Tourism Destination Development}

Through the attributive authority based on Law No. 23 In 2014, the regional government has full authority in managing tourism destinations. It cannot be denied that the role of the government in the management and development policies of tourism destinations must be in line with the objectives of the community so that democracy in the economic sector is created. It can be said that the current that must be created is the top-down and bottom-up current. The bottom-up current is needed as a form of community aspirations that should be accommodated by the government in the form of policy. The aspirations of the community in influencing government policies are manifested in the form of community participation.

Participation according to the Black's Law Dictionary is, as follows: 1) the act of taking part in something; 2) the right of an employee to receive part of business profit [14]. Participation can be defined as an act of participating; participating in an activity, from planning to evaluation [15]. Public participation in the realization of public policy by the government can be categorized as political participation that can be carried out by the community. Political participation by Huntington and Nelson is defined as a private citizen activity aimed at influencing decision making by the government [16]. Participatory method 
(community participation) is inevitable to require in a series of determining tourism development policies, especially management of tourism destinations. Article 1 number 41 of Law No. 23 of 2014 stipulates "Community Participation is the participation of community members to channel their aspirations, thoughts and interests in the administration of Regional Government."

Arnstein in Sirajuddin revealed that there were eight levels of community participation in deciding policies. They are: 1) citizen control; 2) delegated power; 3) partnership; 4) placation; 5) consultation; 6) informing; 7) therapy; and 8) manipulation [16]. If we look at those 8 types of community participation models, they each have different effectiveness in influencing government policy in determining a decision in the realm of public law. Furthermore Sirajuddin classifies 8 types of levels of participation into 3 different levels. Points 1-3 are classified into the Degree of citizen Power level, 4-6 are classified into the Degree of Tokenism, 7 and 8 levels are classified into the level of non-participation. Thus, ideally the form of participation of local communities in the management of tourism destinations is in the form of community control, delegation of power or partnership [16]. From various forms of community participation (business actors) in tourism areas, methods 16 are developable. If the community (business actor) is granted a broad space for participation in government policy making, the results in the form of policies from the government will not create a gap with the needs of the community. Giving opportunities to the community (small business actors) to be actively involved in the development of tourism destinations in line with the ideals of realizing the welfare of the community in tourism destinations (tourism destinations) through the tourism sector. Thus, the location of the nature of regulation about small business actors in tourism development lies in the top-down and bottom-up method. Bottom-up is realized by public participation to support the sociological, philosophical and economic aspects of a policy. While top-down, is the embodiment of government power in the form of legal policies and legal rules that will later apply to legal characteristics that regulate and contain sanctions. Thus, it is hoped that the legal policies or rules in managing small business arrangements have the value of validity as well as effectiveness, especially in the context of the development of tourism areas.

\section{Conclusion}

The implementation and development of tourism is in line with the national development orientation, namely people's welfare creation. Therefore, tourism development efforts cannot override the social dimension (small business actors) that will fulfill sociological, philosophical and economic aspects. Notwithstanding, the nature of the administration of the state is to advance the welfare of its people, so that the interests of the public, especially small business actors in tourism development, must also be accommodated in it. Looking at the construction as mentioned above, it can be seen that there is a decent nature of the development of top-down and bottom-up methods that are systematically structured which serve as a step in determining legal policies or regulations in the context of structuring small businesses in tourism areas. Bottom-up is realized by public participation to support the sociological, philosophical and economic aspects of a policy, while top-down is the embodiment of government power in the form of legal policies and legal rules which later apply with legal characteristics that regulate and contain sanctions. Thus, the policy or rule of 
law in regulating the arrangement of small business actors is expected to have a value of validity as well as effectiveness, especially in the context of the development of tourism areas.

\section{References}

[1] R. C. Mill, Tourism, the International Business. Switzerland: Jacobs Foundation, 2009.

[2] A. Morrison and R. Teixeira, "Small business performance: A tourism sector focus," J. Small Bus. Enterp. Dev., vol. 11, no. 2, pp. 166-173, 2004.

[3] J. Kitching, M. Hart, and N. Wilson, "Burden or benefit? Regulation as a dynamic influence on small business performance," Int. Small Bus. J. Res. Entrep., vol. 33, no. 2, pp. 130-147, 2015.

[4] F. Emery, “Alternative futures in tourism," Int. J. Tour. Manag., vol. 2, no. 1, pp. 49-67, 1981.

[5] W. I. B. Putra, Hukum Bisnis Pariwisata. Bandung: Refika Aditama, 2003.

[6] Soedjono, Sosiologi. Bandung: Penerbit Alumni, 1982.

[7] G. I. D. Atmadja, Ilmu Negara: Sejarah, Konsep, Dan Kajian Kenegaraan. Malang: Setara Press, 2012.

[8] F. Sugianto, Economic Approach To Law, seri II. Jakarta: Kencana Prenada Media Group, 2013

[9] S. Dirjosisworo, Filsafat Hukum dalam Konsepsi dan Analisa, Alumni Bandung, Darji Darmodihardjo, Dardji dan Sidarta, 2006, Pokok-Pokok Filsafat Hukum: Apa dan Bagaimana Filsafat Hukum Indonesia. Jakarta: Gramedia Pustaka Utama, 1984.

[10] L. T. Sargent, Contemporary Political Ideologies: A Comparative Analysis. Chicago: The Dorsey Press, 1984.

[11] L. Rasjidi and T. I. Rasjidi, Pengantar Filsafat Hukum. Bandung: Mandar Maju, 2002.

[12] J. S. Mill, On Liberty, translated in Indonesian Alex Lanur, OFM. Jakarta: Yayasan Obor Indonesia, 2005.

[13] Kaelan, Pendidikan Pancasila. Yogyakarta: Paradigma, 2014

[14] B. A. Garner, Black's Law Dictionary, Ninth Edition. USA: West Publishing, 1999.

[15] H. Halim, Cara Praktis Menyusun Dan Merancang Peraturan Daerah (Suatu Kajian Teoritis Dan Praktis Disertai Manual): Konsepsi Teoritis Menuju Artikulasi Empiris. Jakarta: Kencana Prenada Media Group, 2009.

[16] Sirajuddin, Legislatif Drafting: Pelembagaan Metode Partisipatif Dalam Pembentukan Peraturan Perundang-Undangan. Malang: Setara Press, 2015. 